\title{
ANALYSIS TRAINING NEEDS ASSESMENT DALAM MENINGKATKAN SOFTSKILL KEPROFESIAN GURU (STUDI KASUS DI SMK PGRI 28 JAKARTA)
}

\author{
Septiana Ika Ningtyas ${ }^{1(*)}$, Wiriadi Sutrisno ${ }^{2}$ \\ Universitas Indraprasta PGRI, Indonesia ${ }^{12}$ \\ septiana_ningtyas@yahoo.com ${ }^{1}$, wiriadisutrisno@gmail.com ${ }^{2}$
}

Received: 02 Maret 2020

Revised: 06 Maret 2020

Accepted: 17 Maret 2020

\begin{abstract}
Pendidikan memiliki peranan penting dalam mempersiapkan SDM yang berdaya saing dan bernilai jual karena melalui pendidikan itulah sebagai manusia mendapat pengajaran, ketahanan mental serta penerapan moral dan akhlak sehingga tercipta manusia sebagai tenaga kerja yang bermutu, siap pakai dan berdaya saing. Tenaga kerja terampil dibutuhkan untuk membimbing dan membina para generasi muda untuk menjadi seorang yang kompeten pula. Sebagai contoh guru dimana ketrampilannya dalam mengajar serta mendidik siswa dengan berbagi metode sehingga mampu menelurkan generasi/bibit unggul yang siap bersaing. Keprofesian guru yang cukup penting dalam menghasilkan bakat dan generasi unggul untuk pembangunan nasional nantinya rasanya patut diapresiasi terlebih lagi softskill yang dimiliki para guru harus ditingkatkan, untuk itu pemerintah telah memfasilitasi kebutuhan pengembangan keprofesionalan guru dalam pelaksanaannya melibatkan sekolah. Ini berarti bahwa semakin banyak pengalaman mengajar, guru dituntut semakin tinggi tingkat kompetensi mengajarnya. Kebutuhan akan softskill juga haruslah dimiliki oleh para guru dalam melakukan pengajaran khususnya bagi siswa SMK dimana sudah dinyatakan siap pakai dan bersaing di dunia industri. Contoh kasus SMK PGRI 28 sendiri karena apabila menginginkan siswa yang memiliki softskill, maka guru pun juga layaknya menguasai ilmu "soft skill" tersebut. Sehingga dapat tercipta timbal balik yang efektif dan siswa memiliki bekal yang cukup saat lulus nantinya.
\end{abstract}

Keywords: Training Needs Assessment, kebutuhan softskill, keprofesian guru

(*) Corresponding Author: Septiana Ika Ningtyas, septiana_ningtyas@yahoo.com, 089672226687

How to Cite: Ningtyas. S. I., \& Sutrisno, W. (2020). Analysis training needs assesment dalam meningkatkan softskill keprofesian guru (studi kasus di smk pgri 28 jakarta). Research and Development Journal of Education, 6(2), 49-58.

\section{INTRODUCTION}

Terciptanya kemajuan suatu negara serta kestabilan perekenomian salah satunya dilihat dari jumlah tenaga kerja terampil yang kompeten di bidangnya masing-masing. Hal tersebut terwujud apabila SDM yang dimiliki juga unggul dan juga berkualitas sehingga dalam peranannya memiliki etos kerja tinggi yang memajukan posisi industri yang nantinya dapat meningkatkan perekonomian negara. Sebagai bangsa yang berkembang tentulah harus memiliki keuletan dan daya tanggap yang cepat agar menyesuaikan kiprah dalam tatanan dunia baru yang cepat berubah karena itu pula perlu penyiapan SDM yang berkualifikasi, seperti (1) memiliki keterbukaan baik nalar ataupun pandangan dengan bangsa lain; (2) berperilaku adaptif dan inovatif sebagai antisipasi dengan segala kemajuan zaman yang cepat berubah; (3) mampu untuk berpikir kritis, terbuka dan selalu belajar hal baru; (4) memiliki berbagai keterampilan unik yang mudah 
dilatih ulang; dan (5) memiliki dasar-dasar kemampuan menjalin networking yang luas, mendasar dan kokoh untuk selalu berkembang.

Kendatinya hanya tenaga kerja yang terampil dan kompeten serta memiliki keunikan di bidangnya yang siap untuk bersaing di dunia industri. Salah satunya adalah para lulusan SMK yang sejak dulu dikenal lulusan yang paling mudah mendapatkan pekerjaan yang diinginkan, namun fenomena yang terjadi saat ini berkata sebaliknya, Badan Pusat Statistik (BPS) mencatat terdapat 7,05 juta orang sebagai jumlah pengangguran terbuka dan didominasi oleh para lulusan SMK hingga mencapai 10,42 persen per Agustus 2019. Hal tersebut tentulah cukup mengejutkan karena stigma yang terlanjur tertera lulusan SMK siap kerja. Dalam hal ini bukan hanya kompetensi yang diragukan namun juga terbatasnya ketrampilan atau softskil yang mereka miliki sehingga tidak mampu bersaing dengan lulusan lain di dunia industri. Softskill yang terbatas dan ketrampilan yang minim dimiliki oleh siswa SMK cenderung pada bagaimana guru mendidik serta menerapkan berbagai ketrampilan serta softskill yang sedang dibutuhkan dunia industri saat ini.

Perkembangan dunia industri sangat cepat ditambah lagi adanya distrupsi di berbagai bidang yang memaksa semua orang untuk cepat beradaptasi dan berinovasi agar tidak tertinggal, begitupun juga dengan kemampuan guru dalam memberikan pengajaran serta didikan kepada siswa, siswa yang memiliki ketrampilan dan kemampuan yang handal bergantung pada guru yang juga harus memiliki softskill yang mumpuni, ketrampilan mengajar yang kreatif dan kecerdasan yang baik. Peran guru sebagai suatu profesi justru malah dipertanyakan karena sudah selayaknya sebuah profesi pasti memerlukan ketrampilan serta softskill yang memadai.

Pemerintah Indonesia, saat itu melalui Departemen Pendidikan Nasional telah mengeluarkan Undang-Undang Nomor 14 tahun 2005 tentang Guru dan Dosen dimana salah satunya membahas peningkatan kualitas melalui uji sertifikasi dan kualifikasi guru. Berbagai cara dilakukan untuk meningkatkan kualitas pendidikan melalui perbaikan kurikulum, kesempatan belajar bagi guru, peningkatan kesejahteraan guru melalui tunjangan profesi guru, dan memfasilitasi Pengembangan Keprofesionalan Guru Berkelanjutan. Pengembangan peningkatan guru yang selama ini berjalan tidaklah berkelanjutan, dalam artian peningkatan kualitas profesi guru tidak dilakukan sebagai proses yang dilakukan terus menerus tetapi sering kali hanya bersifat program dan terjadi saat itu saja, dengan demikian pelaksanaan peningkatan profesional sering terhenti dengan berhentinya program atau proyek tersebut, padahal pembinaan harus merupakan progress yang terus berkesinambungan.

Di sisi lain, pembinaan juga lebih banyak mengacu pada pengembangan hal-hal yang bersifat teoritis dan terkadang hanya sebagai terlaksananya program sehingga pembinaan dari aspek afektif dan psikomotorik yang termasuk di dalam kemampuan softskill amatlah kurang. Sudah semestinya pengembangan ketrampilan terutama softskill guru menjadi keharusan dalam rangka menciptakan guru-guru yang unggul, cakap, berdaya saing, inovatif dan berjiwa kuat dalam dalam mengatasi segala persoalan pendidikan khususnya pada era globalisasi dan kecanggihan teknologi di bidang pendidikan saat ini.

Kebutuhan soft skill juga haruslah dimiliki oleh para guru di SMK PGRI 28 sendiri karena apabila menginginkan siswa yang memiliki soft skill yang baik, maka guru pun juga layaknya menguasai ilmu "soft skill" tersebut. Sehingga dapat tercipta timbal balik yang efektif dan siswa memiliki bekal yang cukup saat lulus nantinya. Dari paparan masalah diatas, maka tim peneliti Unindra tertarik untuk membuat penelitian yang berjudul : Analisis Training Needs Assessment dalam Meningkatkan Softskill Keprofesian Para Guru SMK PGRI 28 Jakarta. 


\section{KAJIAN PUSTAKA}

\section{Traning Needs Assesment}

Analisis kebutuhan pelatihan (training need analysis) direncanakan dan dilaksanakan untuk memperoleh sejumlah data atau informasi tentang kondisi dan kebutuhan pegawai dalam melaksanakan tugasnya. Pemahaman akan analisis kebutuhan pelatihan perlu dilakukan sebelum pelaksaan pelatihan itu sendiri guna meihat secara terperinci bagaimana dan apa yang sebenarnya dibutuhkan oleh suatu lembaga atau organisasi, sehingga trainer dapat melihat secara zoom in dan zoom out. Karena itu analisis kebutuhan pelatihan haruslah melibatkan tiga kegiatan yaitu analisis organisasi, analisis kinerja dan analisis individu. Training Needs Assessment (TNA) is "The way how to specify what training need or what training required. The TNA procedures is to look for accurately the level of situation in every survey like observations, interview, seminar or workshop". (Project on Improvement of Local Administration in Cambodia (PILAC) Ministry of Interior and Japan International Cooperation Agency).

Pengertian tersebut diatas diartikan suatu cara untuk menentukan adanya sebuah kebutuhan pelatihan. TNA sebagai langkah untuk mengidentifikasi secara akurat pada tingkatan situasi saat ini dalam survei yang telah ditentukan, hasil wawancara, observasi, seminar atau workshop. Makna dari TNA adalah "melihat secara terperinci serta mencari data secara menyeluruh" (Irianto, 2001:29). Hal yang sering ditemukan pada kasus yang diujikan melalui TNA mayoritas mengarah pada pemahaman bebrapa orang terhadap makna dari kinerja yang muncul saat terjadi perbedaan antara hasil kerja yang diharapkan dengan yang sebenarnya terjadi pada guru dalam kasus ini atau bisa juga diartikan adanya ketimpangan antara kemampuan yang diharapkan dengan kemampuan yang dimiliki oleh guru.

Selain itu TNA juga didefinisikan sebagai "sebuah proses untuk mengidentifikasi kesenjangan terhadap kebutuhan training, dimana memudahkan trainer dalam menganalisa dan memberikan training dengan tepat atau sesuai kebutuhan" (Riani, 2013). TNA biasanya mengacu pada Key Performance Indicator (KPI) dengan alasan untuk mengurangi kesenjangan yang terlihat pada pemangku jabatan.

\section{Pengertian Soft skills}

Soft skills adalah kemampuan seseorang untuk berperilaku secara pribadi maupun berkaitan dengan orang lain dengan memaksimalkan kinerja seperti berpikir, bertindak cepat, kerjasama tim, insiatif serta pembuat keputusan. Pemahaan mengenai Soft skills bukan sesederhana seperti ketrampilan yang dilakukan secara langsung seperti, memasak, merapikna baju atau merakit komputer tetapi mencakup ketrampilan yang didapatkan melalui pemberian motivasi, pemberian nilai-nilai positif yang diberlakukan dalam pembelajaran yang dapat melengkapi kemampuan akademik dan kemampuan yang seharusnya dimiliki oleh setiap orang, apapun profesi yang ditekuni seperti perawat, guru, pelatih olah raga dan lain sebagainya.

Soft skills diartikan sebagai "kemampuan non teknis yang dapat dilihat dari pembawaan, nilai yang terkandung melalui sikap dan perilaku baik dengan diri sendiri ataupun orang lain." Ketrampilan softskill, meliputi nilai positif yang dimiliki, kebiasaan, bakat, hasrat, dan kemauan, Softskill yang dimiliki oleh setiap orang tentunya berbeda, dapat dipengaruhi oleh kemauan untuk berubah, kebiasaan berpikir, berinteraksi dengan orang dan bertindak.

Secara garis besar softskill didefinisikan sebagai "kemampuan berperilaku, keterampilan dalam memahami kepribadian orang lain, karakteristik serta kebiasaan dibandingkan dengan segi intelegensi atau teknis." (J. Mahasneh, 2015). Softskill merupakan potensi yang dimiliki seseorang dan merupakna bagian dari perilaku serta 
kebiasaan (Abdunawi, 2012). Softskill merupakan "bagian dari kemampuan perorangan untuk yang lebih mengarah pada sisi afektif, cara memperlakukan tiap-tiap orang dengan lebih sensitif terhadap lingkungan sekitar." (Endang\&Elisabeth, 2015).

Softskill dikategorikan menjadi 2 golongan yaitu; intrapersonal dan interpersonal skills, intrapersonal skill diantaranya self management, self assessment, self effication, sef confident, trust, self control. Sedangkan interpersonal skill adalah leadership, social awareness, diversity, tim building, coordination, communication, etc. (Endang\&Elisabeth, 2015). Sehingga dapat dianalisa bahwa softskill merupakan bagian dari cara mengetahui kepribadian seseorang melalui tingkah laku, kebiasaan, sifat serta pengaruh yang mengikuti orang tersebut.

\section{Profesionalisme Guru}

Seorang guru yang dikatakan profesional haruslah memiliki kompetensikompetensi yang seharusnya dimiliki oleh guru. Sebuah profesi diartikan sebagai kemampuan seseorang dalam menekuni sebuah pekerjaan atas dasar intelektualitas, keahlian dan ketekunan (Yamin, 2007). Profesi guru merupakan ketrampilan atau keahlian yang mengarah pada pengajaran sebagai bagian dari pekerjaan yang ditekuninya (Kunandar, 2007).

Bagaimanapun sebuah profesi haruslah dikerjakan secara profesional terlebih lagi seorang guru sosok yang ditiru dan menjadi panutan siswa, sikap profesional haruslah sudah menjadi bagian dari sikap dan kebiasaannya. Seorang guru yang profesional merupakan orang yang mempunyai ketrampilan atau bakat khusus dalam memberikan pendidikan kepada siswa secara optimal (Sudaryono, 2012).

Sehingga dapat disimpulkan menjadi seorang guru yang profesional merupakan bakat atau panggilan hati karena memberikan pendidikan dan pengajaran kepada seseorang bukanlah seperti membetulkan televisi yang hanya perlu sekali pengerjaan melainkan mendidik membutuhkan waktu yang tidak sebentar dan memerlukan evaluasi juga di dalamnya agar proses yang terjadi berjalan sempurna, karena itu diperlukan professionalism seorang guru dalam mendidik siswa.

\section{METHODS}

diantaranya :

Penelitian ini melibatkan beberapa metode dan cara untuk pelaksanannya

\section{Pendekatan Studi dan Metodologi}

\section{a. Pendekatan Studi}

Dalam melakukan Analisis TNA, dilakukan dengan beberapa pendekatan sebagai berikut:

\section{1) Studi Literatur}

Kajian literatur untuk melihat berbagai contoh pola pengembangan potens dan kompetensi profesionalitas guru. Studi Literatur yang dilakukan didapatkan dari berbagai sumber pustaka dan laporan studi yang relevan.

\section{2) Pendekatan Partisipatif (Dialog)}

Pendekatan ini dimaksudkan agar perencanaan yang dilakukan sesuai dengan aspirasi para stakeholder (pimpinan, guru, tenaga pendukung dan peserta didik) sehingga manfaat pengembangan kompetensi guru tersebut dipahami dan memiliki guna sebesar-besarnya. Pendekatan ini dilakukan dengan melakukan sosialisaasi kegiatan baik melalui presentasi di hadapan stakeholder maupun sosialisasi melalui media massa dengan harapan mendapat masukan (feedback) terhadap kegiatan yang dilakukan. Harapan 
lainnya adalah munculnya komitmen seluruh stakeholder untuk bersama saling mengembangkan potensi demi terwujudnya mutu pendidikan yang berkualitas.

\section{3) Pendekatan Survey Komprehensif}

Pendekatan survey disini bertujuan untuk mendapatkan gambaran yang nyata mengenai situasi dan kondisi lapangan, baik untuk menentukan jenis kegiatan yang perlu diintrodusir maupun pemetaan alternatif lokasi penerapan alternatif rancana pengembangan SMK. Selain itu juga mendapatkan masukan dan aspirasi langsung dari pengguna baik dari peserta didik, orang tua, dan pengguna (instansi pemerintah dan swasta).

4) Pendekatan Training Need Assessment

Untuk penyusunan modul pelatihan dilakukan beberapa kegiatan antara lain:

a) Workshop penyusunan instrumen modul melalui survey collecting data, dalam rangka penentuan jenis dan jumlah modul; Workshop dilakukan dengan PPK untuk mendiskusikan instrumen-instrumen yang akan digunakan pada saat pengumpulan data. Instrumen yang akan digunakan sebelumnya disiapkan oleh Peneliti Unindra untuk kemudian difinalisasi melalui kegiatan workshop di lingkungan penyelenggara SMK.

b) FGD try out modul, Untuk menjamin kualitas modul, dilaksanakan FGD dengan PPK. FGD ini membahas modul-modul yang telah disiapkan oleh Peneliti Unindra dan diuji cobakan dalam FGD. Modul-modul yang telah diuji cobakan diperbaiki sesuai dengan masukan-masukan dari PPK dan pihak-pihak terkait lainnya sebelum diterapkan dilapangan (SMK).

c) Koordinasi dengan pengelola SMK dan identifikasi target group Competence Based Training.

\section{b. Metodologi}

Penelitian yang dilakukan secara kualitatif dengan melakukan wawancara mendalam (in depth interview) untuk mengkonfirmasi kebenaran data tersebut juga dilengkapi dengan pengamatan dan wawancara kepada tokoh masyarakat.Dalam pengumpulan data tentang profil digunakan teknik-teknik seperti Focus Group Discussion (FGD)

\section{1) Teknik Pengumpulan Data}

Data yang akan dikumpulkan dalam penelitian ini adalah data primer dan data sekunder yang diperoleh dari stake holder yang ada SMK PGRI 28 baik dari data diambil melalui wawancara, observasi lapangan dan dokumentasi.

a) Data Primer

Jenis data yang diambil adalah data yang dari sumbernya (SMK), baik dari pengelola, Tenaga Perbantuaan, Guru dan Peserta Didik.

b) Data Sekunder

Merupakan data atau informasi yang diperoleh dari studi literatur, seperti buku-buku, jurnal, makalah kajian-kajian berkaitan sebelumnya, serta data yang telah diteliti sebelumnya yang digunakan sebagai landasan teori dari hasil penelitian sebelumnya, yang diperoleh dari jurnal, makalah, maupun berbagai situs resmi pemerintah atau swasta sebagai contoh Biro Pusat Statistik (BPS) dan lain-lain. Data untuk variabel-variabel penelitian, yang diambil dari penelitian yang berkaitan sebelumnya. Data sekunder membantu untuk menjawab tujuan survey secara langsung atau untuk verifikasi. Data memiliki peran penting dalam menentukan keberhasilan kajian, karna data harus memiliki validitas tinggi, yang berkaitan dengan ketersedian data atau sumber asal data. Data sekunder dikumpulkan dari 
sumber terpercaya, seperti laporan ilmiah (jurnal dan prosiding), laporan tahunan atau laporan lain yang terbitkan oleh instansi terkait (Kementerian Pendidikan). Data sekunder dikarapkan dapat memberikan informasi rinci tentang kondisi pendidikan di Indonesia. Pengumpulan data sekunder dibagi menjadi dua gugus (cluster) yaitu Perturan Pendidikan Tingkat SLTA secara Nasional, Pendidikan vokasi (SMK).

\section{RESULTS \& DISCUSSION}

Dari hasil olah data dan serangkaian analisis yang telah dilakukan di SMK PGRI 28 Jakarta diperoleh masukan yang pembahasannya dapat dicermati sebagai berikut:

\section{Analisis SWOT}

a. Kekuatan (Strength)/S

Dari hasil survey, diperoleh fakta bahwa kekuatan yang ada pada lembaga pendidikan vokasi serta kualitas SDM guru SMK PGRI 28 Jakarta adalah:

- S01, Pemerintah sudah memberikan perlindungan hukum melalui (UURI No. 14 Tahun 2005) tentang peningkatan kompetensi guru melalui uji sertifikasi dan peningkatan kualifikasi pendidikan guru.

- S02, Pemerintah memberikan insentif tambahan bagi Guru yang berkualitas.

b. Kelemahan (Weakness)/W

- W01, belum adanya kebutuhan akan training soft skill yang terorganisasi bagi para tenaga pengajar di SMK PGRI 28 Jakarta

- W02, kurang adanya akses untuk berinteraksi langsung dengan pihak yayasan

\section{c. Kesempatan (Oppurtunities)/ O}

- O01, Pemerintah telah memfasilitasi kebutuhan pengembangan keprofesionalan guru.

- O02, Atas keprofessionalitas guru pemerintah memberikan insentif setelah melalui uji sertifikasi guru.

\section{d. Ancaman (Threats)/T}

- T01, Kualitas guru khususnya dibidang soft skill tidak mampu menghasilkan kualitas anak didik yang tidak memiliki daya saing tinggi

- T02, Rendahnya kualitas guru mengakibat metode pembelajaran tidak link and match dengan kebutuhan industri

Dari analisis SWOT, WT adalah simbol yang sangat kritis terjadi pada para guru SMK PGRI 28 Jakarta. Karena keterbatasan kompetensi dalam mempresentasikan kualitas megajar, maka produk mengajar yang disajikan kurang maksimaal. Sehingga para peserta didik tidak memperoleh nilai tambah dari hasil PBM yang diperoleh dan hal ini menyebabkan kualitas dan kompetensi yang diperoleh para peserta didik tidak mengalami kemajuan hari demi hari.

\section{Strategi $T N A$}

Dengan mengacu pada kondisi para guru SMK PGRI 28 Jakarta serta analisis SWOT yang sudah dilakukan, maka disimpulkan strategi yang tepat dan sesuai untuk memenuhi kebutuhan pelatihan/pendampingan bagi guru adalah sebagai berikut:

a. Pendampingan/pelatihan Interpersonal skill kepada para guru SMK PGRI 28 Jakarta, yang terdiri dari :

1) Dasar keterampilan sosial dan berinteraksi dengan mitra guru dan peserta didik dengan percaya diri.

2) Jaringan kerja baik diantara sesama mitra guru dan peserta didik secara efektif. 
3) Prinsip, perencanaan, proses dan taktik negosiasi, dalam mempersiapkan bahan ajar agar terdapat kesuaian baik dengan pedoman mengajar yang sudah ditentukan maupun dengan mitra guru lainnya

4) Ketidak percayaan diri dalam berhubungan dengan para audiens, mitra guru, peserta didik luar sekolah maupun peserta didik sendiri

5) Materi presentasi, teknik menggunakan suara, bahasa tubuh dan alat bantu presentasi, dalam menyampaikan materi (bahan ajar) kepada peserta didik

6) Mentalitas sebagai penjual (salesmanship) dan mampu mengatasi kekhawatiran akan penyampaian materi kurang diterima audiens, khususnya peserta didik

7) Analisis kebutuhan, presentasi dan mengatasi kekurang fahaman peserta didik dalam menyampaikan materi ajar.

b. Pendampingan/pelatihan Intra personal Skill kepada para guru SMK PGRI 28 Jakarta, yang terdiri dari :

1) Membangun kepercayaan diri, kemampuan individu untuk dapat memahami dan meyakini bahwa dirinya potensial serta dipergunakan untuk menyesuaikan diri terhadap lingkungan belajar dan mengajar.

2) Memiliki jiwa pantang menyerah, adaptif serta inovatif terhadap masa depan, menyadari konsep dirnya dan menyebutkan kelemahan dan kelebihan diri sendiri, berpikir positif, menganggap semua permasalahan pasti ada jalan keluarnya, guna menjadikan.

3) Sadar akan potensi serta tantangan yang ada dalam dirinya. Seorang guru dapat menilai dirinya sendiri, maka otomatis ia akan selalu berintrospeksi sehingga dirinya akan terus berkembang untuk lebih baik.

4) Mengenali dan memahami perasaan sewaktu perasaan itu terjadi. Jika seorang guru mampu untuk mengendalikan emosinya maka segala urusan dan pekerjaan yang berkaitan dalam proses belajar mengajar dapat terselesaikan dengan baik.

5) Bertanggung jawab atas profesinya. Segala tingkah laku yang lakukan berasal dari inisiatif guru sendiri. Jadi seorang guru selalu berusaha menghasilkan sesuatu yang produktif, maka apa saja yang dikerjakan seorang guru akan memiliki dampak yang baik terhadap proses belajar mengajar.

Kemudian untuk melihat secara jelas differensiasi antara pre test dan post test, disajikan dalam diagram laba-laba seperti terlihat pada diagral laba-laba pelatihan dan pendampingan interpersonal skill.

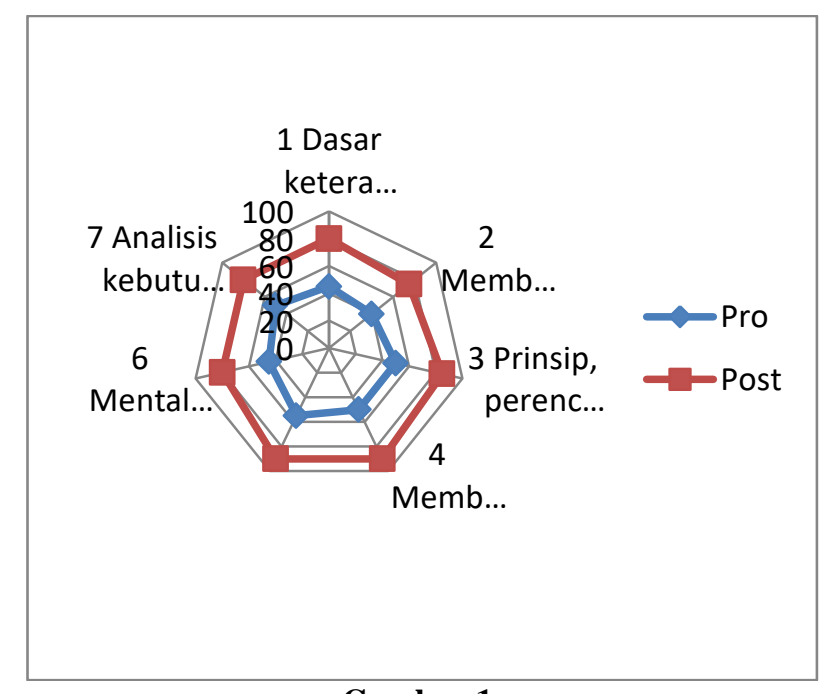

Gambar 1.

Diagram Laba-laba dari hasil Pelatihan dan Pendampingan 


\section{Interpersonel Skill}

Selanjutnya, untuk mengetahui penguasaan intrapersonal skill, terlebih dahulu peneliti melakukan analisis exixting condition (kondisi saat ini) yang dimiliki para guru, dengan melakukan before dan after analisi. Sebelum (before) pelatihan dan pendampingan, para guru menjalani pre-test. Secara rata-rata, hasil test penguasaan teknik interpersonal skill terhadap 30 orang guru SMK PGRI 28 Jakarta, disajikan pada table hasil pelatihan dan pendampingan intrapersonal skill.

Kemudian untuk melihat secara jelas diferensiasi antara pre-test dan post- test, disajikan dalam diagram laba-laba seperti terlihat pada diagram laba-laba pelatihan dan pendampingan intrapersonal skill.

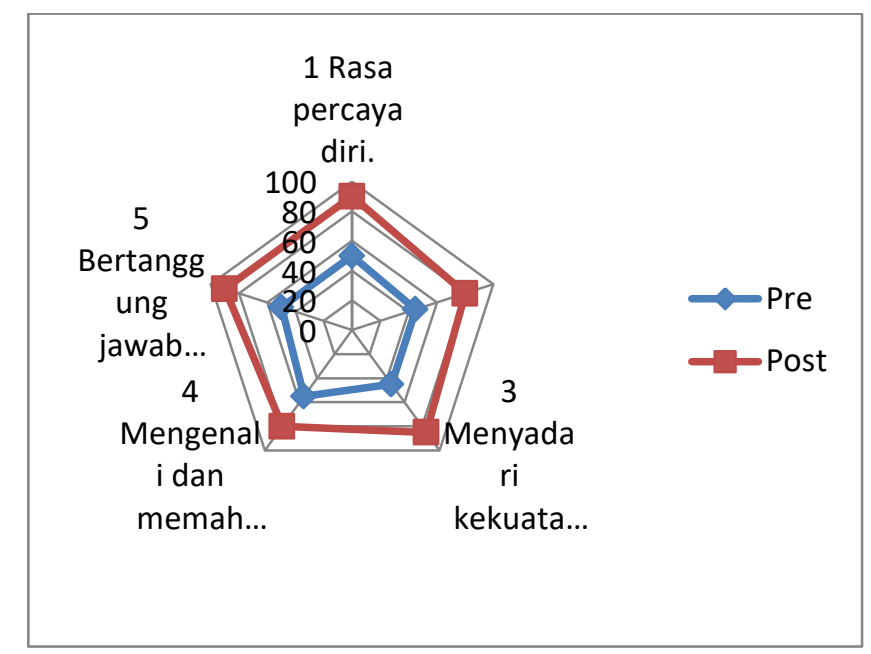

Gambar 2.

Diagram Laba-laba dari hasil Pelatihan dan Pendampingan Interpersonel Skill

\section{CONCLUSION}

1. Kegiatan pendampingan dilakukan selama penelitian berlangsung dimana peneliti menggunakan analisis SWOT untuk merinci lebih jelas serta treatment apa yang dibutuhkan agar tepat mengenai sasaran. Dilakukannya metode pre-test dan post-test untuk mengetahui seberapa besar para guru dalam memahami softskill yang ia miliki untuk kebutuhan proses belajar mengajar di kelas, softskill yang dicuatkan disini adalah interpersonal skill dan antarpersonal skill, kemudian peneliti membaginya dalam 2 pembahasan berikut juga dengan soal pre-test dan post-test agar penyelesaian yang dilakukan menjadi jelas dan terarah. Dari pre-test dan post-test yang dilakuan oleh para guru-guru tercatat bahwa sebelum diberikan pelatihan, pendampingan, mentoring dan lain lain mayoritas hasil pre-test lebih rendah atau sama dengan score terendah kemudian peneliti memberikan pelatihan dan pendampingan interpersonal skill guru dalam kurun waktu yang telah ditentukan dengan indikator atau materi terkait setelah pendampingan tersebut peneliti kembali membagikan soal (post test) untuk guru kerjakan dan hasilnya jauh lebih baik dibandingkan dengan pre-test sebelumnya. Hasil pelatihan dan pendampingan dengan materi intrapersonal skill juga demikian, dimana pada saat pre-test hasilnya kurang begitu baik namun setelah dilakukan pelatihan berupa simulasi, pelatihan dan pendampingan, hasil post-testnya dinilai cukup baik. 
2. Analisis hasil test (pre-test dan post-test)

Untuk lebih mempermudah dalam proses menganalisis maka peneliti membuat score dalam range 0-100 kemudian membuat diagram laba-laba untuk menentukan range tertinggi berada pada indikator apa, sehingga untuk penelitian selanjutnya, peneliti akan lebih mudah untuk mengindentifikasi daerah atau bagian apa yang memerlukan pelatihan lebih khusus dan mendalam.

3. Dampak pelatihan dan pendampingan bagi guru

Sebelum dilakukannya pre-test dan post test, para guru diwawancarai secara acak terkait dengan penguasaan intrapersonal dan interpersonal skill agar peneliti dapat menganalisis kondisi yang terjadi saat ini dan setelahnya baru peneliti melakukan pretest dan post test. Hasil dari dilakukannya Training Needs Analysis agar para guru mendapatkan pemahaman secara lebih mendalam mengenai softskill yang harusnya dimiliki terlebih lagi era distrupsi saat ini. Guru di SMK PGRI 28 merespon secara antusias dan senang dikarenakan mendapat ilmu dan pengalaman baru karena materi softskill ini merupakan suatu hal yang cukup baru terlebih lagi pemahaman akan interpersonal dan intrapersonal skill sehingga melalui pendampingan dan pelatihan ini membuat para guru lebih percaya diri serta turut aktif dalam mengembangkan diri dan potensinya.

\section{REFERENCES}

Abdunawi, A. (2012). The Value and Development of Softskill : The Case of Oman. International Journal of Information Technology and Bussines Management, 8788.

Anita Kristina. (2013). Model Training Needs Analysis Untuk Membentuk Perilaku Inovatif SDM Industri Kecil Sepatu Di Jawa Timur Pamator, Volume 6, Nomor 1.

Endang \& Elisabeth. (2015). Perilaku dan Softskill Kesehatan. Jakarta: Pustaka Baru Press.

Https://money.kompas.com/read/2019/11/05/155358926/bps-pengangguran-meningkatlulusan-smk-mendominasi diakses tanggal 10 Maret 2020

Isthofaina Astuti. (2010). Evaluasi Program Pelatihan Soft Skill Mahasiswa: Pendekatan Experimental Vol.1, No.2.

J. Mahasneh, W. (2015). Rethinking Construction Curriculum: A Descrptive Cause Analysis For Soft skills Gap. Asc Annual International Conference Proceeding, (pp. 1-8).

Klaus, P. (2008). The hard truth about soft skills, workplace lessons smart people wish they'd learned sooner. Collins, February 1, 2008, Paperback. HarperCollins ebooks

Kunandar. (2007). Guru Profesional Implementasi Kurikulum Tingkat Satuan Pendidikan (KTSP) dan Persiapan Menghadapi Sertifikasi Guru. Jakarta: PT Raja Grafindo Persada.

Peterson, Robyn. (1998). Training Needs Assessment, 2nd ed., Kogan Page practical trainer series, Kogan Page Limited, London.

Riani, A. L. (2013). Manajemen Sumber Daya Insani Masa Kini. Yogyakarta: Graha Ilmu.

Sudaryono. (2012). Dasar-dasar Evauasi Pembelajaran. Yogyakarta: Graha Ilmu.

Syamsul Bachri Thalib. (2010). Psikologi Pendidikan Berbasis Analisis Empiris Aplikatif, Jakarta: Prenada Kencana Group.

Tilaar, H.A.R. (2002). Membenahi Pendidikan Nasional. Jakarta: PT. Rineka Cipta. 
Usman, M.U. (2006). Menjadi Guru Profesional. Bandung : PT. Remaja Rosda Karya. Wikipedia. (2010). Sekolah. http://id.wikipedia.org/wiki/Sekolah

Yamin, M. (2007). Profesional Guru dan Implementasi KTSP. Jakarta: Gaung Persada Press. 